\title{
Antifatigue Effect of Fresh Royal Jelly in Mice
}

\author{
Masaki Kamakura, ${ }^{*}$ Nobu Mitani, Toshiyuki Fukuda and Makoto FukUshima \\ POLA RED Laboratories, POLA Corporation, 560 Kashio-cho, \\ Totsuka-ku, Yokohama 244-0812, Japan
}

(Received June 18, 2001)

\begin{abstract}
Summary We investigated the antifatigue effect of royal jelly (RJ), which had been stored at $-20^{\circ} \mathrm{C}$ from immediately after collection, in male Std ddY mice. The mice were accustomed to swimming in an adjustable-current swimming pool, then subjected to forced swimming five times during $2 \mathrm{wk}$, and the total swimming period until exhaustion was measured. They were separated into three groups with equal swimming capacity, which were administered RJ, RJ stored at $40^{\circ} \mathrm{C}$ for $7 \mathrm{~d}(40-7 \mathrm{~d} \mathrm{RJ})$, or the control solution including casein, cornstarch, and soybean oil before swimming. All mice were forced to swim for 15 min once; then the maximum swimming time to fatigue was measured after a rest period. The swimming endurance of the RJ group significantly increased compared with those of the other groups. The mice in the RJ group showed significantly decreased accumulation of serum lactate and serum ammonia and decreased depletion of muscle glycogen after swimming compared with the other groups, whereas there was no significant difference between the 40-7d RJ group and the control group in these parameters after swimming. A quantitative analysis of constituents in $\mathrm{RJ}$ showed that $57-\mathrm{kDa}$ protein, which we previously identified as a possible freshness marker of RJ, was specifically degraded in RJ stored at $40^{\circ} \mathrm{C}$ for $7 \mathrm{~d}$, whereas the contents of various vitamins, 10-hydroxy-2-decenoic acid, and other fatty acids in RJ were unchanged. These findings suggest that RJ can ameliorate the physical fatigue after exercise, and this antifatigue effect of RJ in mice seems to be associated with the freshness of RJ, possibly with the content of $57-\mathrm{kDa}$ protein.
\end{abstract}

Key Words royal jelly, swimming endurance, antifatigue effect, 57-kDa protein, freshness

Royal jelly (RJ) is the exclusive food of the queen honey bee (Apis mellifera) larva and is secreted from the hypopharyngeal and mandibular glands of the worker honey bees mainly between the sixth and twelfth days of their life $(1,2)$. The chemical composition of RJ was reported to be mainly proteins, sugars, lipids, and vitamins (3-5), together with many bioactive substances such as 10-hydroxy-2-decenoic acid (6), antibacterial protein (7), and a stimulating factor for the development of genital organs in male mice $(8)$. The storage of RJ at high temperature causes various changes such as acceleration of the Maillard reaction and increases of viscosity, acidity, and protein degradation (9). We previously investigated the compositional changes of RJ during storage under various conditions (from $4^{\circ} \mathrm{C}$ to $50^{\circ} \mathrm{C}$ for up to $7 \mathrm{~d}$ ), seeking a factor that could be utilized as a marker for freshness of RJ, and found that 57kDa protein in RJ was specifically degraded in proportion to both storage temperature and storage period, whereas the contents of other constituents in RJ did not change during storage under the conditions examined

\footnotetext{
* To whom correspondence should be addressed.

E-mail: m-kamakura@pola.co.jp

Abbreviations: RJ, royal jelly; $40-7 \mathrm{~d}$ RJ, RJ stored at $40^{\circ} \mathrm{C}$ for $7 \mathrm{~d}$; 10-HDA, 10-hydroxy-2-decenoic acid; RJP-2, royal jelly protein-2; TCA cycle, tricarboxylic acid cycle; EGF, epidermal growth factor; HGF, hepatocyte growth factor.
}

(10). Although a deterioration of the physical properties and a change of chemical composition of RJ during inappropriate storage are known to decrease the physiological activity of RJ, there has been no report on the relationship between the freshness of RJ and its physiological activity.

So far, RJ has been demonstrated to have several physiological activities in experimental animals, including vasodilative and hypotensive activities (11), increase in growth rate (12), disinfectant action (13), antitumor activity (14-17), antihypercholesterolemic activity (18), and antiinflammatory activity (19). Also, RJ has been clinically reported to relieve chronic fatigue syndrome (20) and has been widely used as a nutritional tonic in commercial medical products and health foods in many countries. However, no detailed studies have ever been performed to test whether RJ improves fatigue in vivo.

Recently, Matsumoto et al. developed a swimming pool with a pump that generates waterflow and creates currents to evaluate the exercise capacity of mice after various treatments involving diet and drugs (21). A treadmill has often been used to evaluate the exercise capacity of mice, but the issue that tails of mice were injured during exercising has been reported $(22,23)$. On the other hand, the forced swimming test, in which swimming capacity is measured after weights equivalent to specific body weight percentages have been 
added to the chest or tail of mice, has the problem that it is difficult to measure the swimming times of mice with sufficient reproducibility $(24-27)$. However, the swimming test with an adjustable-current water pool resolves various issues in the other exercise tests and allows reliable and reproducible evaluation of the physical work capacity of mice.

In this study, we used an apparatus with an adjustable-current water pool to evaluate the effect of RJ administration on the endurance capacity of mice. We investigated whether RJ can relieve the exhaustion of mice after exercise, and we studied the relationship between the antifatigue effect on mice and the freshness of RJ.

\section{MATERIALS AND METHODS}

Animals. Five-week-old male Std ddY mice (a closed colony from Japan Shizuoka Laboratory Center, Hamamatsu, Japan) were used and housed in cages $(20 \times 32 \times 14 \mathrm{~cm} ; 5$ mice per cage $)$ under controlled conditions of temperature $\left(23 \pm 3^{\circ} \mathrm{C}\right)$, humidity $(55 \pm$ $15 \%$ ), and lighting (light from $07: 00$ to $19: 00$ ). They were given free access to water and a commercial diet (type MF; Oriental Yeast, Tokyo, Japan). The care and treatment of experimental animals conformed to the guidelines for the ethical treatment of laboratory animals.

Administration of samples. RJ produced by honey bees (Apis mellifera) fed with nectar and pollen from rape (Brassica napus) was used in this study. RJ samples were harvested, immediately frozen, and stored at $-20^{\circ} \mathrm{C}$. RJ that had been stored at $40^{\circ} \mathrm{C}$ for $7 \mathrm{~d}$ was also used as a sample. The mice were orally administered $500 \mu \mathrm{L}$ of $16 \%$ (w/v) RJ solution ( $2 \mathrm{~g} / \mathrm{kg}$ body weight) or a solution containing $16 \%(\mathrm{w} / \mathrm{v}) \mathrm{RJ}$ stored at $40^{\circ} \mathrm{C}$ for $7 \mathrm{~d}$ (40-7d RJ, $2 \mathrm{~g} / \mathrm{kg}$ body weight). RJ used in the present study consisted of $65 \%$ water, $13.2 \%$ protein, $12.1 \%$ sugar, and $4.1 \%$ lipid. Therefore, a control group was orally administered $500 \mu \mathrm{L}$ of the control solution, including $21 \mathrm{mg} / \mathrm{mL}$ casein, $19 \mathrm{mg} / \mathrm{mL}$ cornstarch, and $6.6 \mathrm{mg} / \mathrm{mL}$ soybean oil (264 mg casein, $242 \mathrm{mg}$ cornstarch, and $82 \mathrm{mg}$ soybean oil/kg body weight), which provides the same total energy as RJ. The control solution was used to ensure that any observed effect of RJ was not simply because of the nutritive value of RJ as an energy source.

Adjustable-current swimming pool. An adjustablecurrent water pool was used to determine swimming capacity. The details have been described elsewhere (21). We used an acrylic plastic pool $(90 \times 45 \times 45 \mathrm{~cm}$; Anitec Co., Otsu, Japan) filled with water to a depth of $38 \mathrm{~cm}$. The inner surface of the pool is flat and smooth to prevent an animal from supporting itself while swimming. The current in the pool is generated by circulating water with a pump (type C-P60J, Hitachi, Tokyo, Japan). Water is returned to the pump through a narrow slit in a plastic pipe set at the bottom of the pool. The strength of the current can be adjusted by changing the water flow, which is regulated by opening or closing a valve, and is monitored by a water flow meter
(FC-A20, Flow Meter Laboratory, Tokyo, Japan). The distribution of the surface-current speed is measured with a digital current meter (type SPC-5, Sanko Industry, Tokyo, Japan) at 12 surface points spaced at regular intervals. The temperature of the water is maintained at $34^{\circ} \mathrm{C}$ with a water heater and thermostat. High reproducibility and sensitivity of this apparatus for evaluating the maximum endurance of mice have been reported $(21,28,29)$.

Measurement of the maximum swimming time in the adjustable-current pool. To avoid circadian variations in physical activity, the experiments were done from 13 : 00 to $17: 00$, a period in which the minimal variation of swimming capacity has been confirmed in mice (21). All mice were given a 1-wk preliminary period during which they became accustomed to swimming; then the maximum swimming time (endurance) was measured at a flow rate of $8 \mathrm{~L} / \mathrm{min}$ five times during $2 \mathrm{wk}$ for the division of mice into appropriate groups. The mice were assessed to be fatigued when they failed to rise to the surface of water to breathe within a 7-s period. A period of longer than $7 \mathrm{~s}$ resulted in frequent drowning, and less than 5 s reduced the reproducibility of the test (21).

Experimental design. In this study, the mice were forced to swim again after swimming once, and the maximum swimming times and metabolic parameters during the second swim, which followed a rest period, were measured to evaluate the antifatigue effect of preadministered samples on the mice. Eighty mice were made to swim for $15 \mathrm{~min}$ during a $1-\mathrm{wk}$ preliminary period to become accustomed to swimming; then they were subjected to forced swimming until exhausted. The maximum swimming time (endurance) was measured five times during $2 \mathrm{wk}$. The mice were separated into four groups (Groups 1-4), and the mice in each group were divided into three subgroups with equal swimming capacity and body weight. The three subgroups in each group were administered RJ, 40-7d RJ, or the control solution at $48 \mathrm{~h}, 24 \mathrm{~h}$, and $0.5 \mathrm{~h}$ before swimming. After administration, blood samples of mice in Group $1(n=19)$ were immediately collected from the jugular veins, and the concentrations of lactate, ammonia, and glucose in the blood were determined. The gastrocnemius muscles were also removed and stored at $-80^{\circ} \mathrm{C}$, and the glycogen concentration in muscle was measured. The mice in Group $2(n=14)$ were then subjected to forced swimming for $15 \mathrm{~min}$, blood samples and gastrocnemius muscles were collected, and the same parameters as before were measured. Furthermore, the mice in Group $3(n=24)$ were forced to swim for $15 \mathrm{~min}$ and were made to take a rest for $30 \mathrm{~min}$. They were again subjected to forced swimming for $15 \mathrm{~min}$, following the oral administration of RJ, 40-7d RJ, or the control solution at $10 \mathrm{~min}$ after the start of the rest period. Thereafter blood samples and gastrocnemius muscles were collected, and the same parameters as before were measured. The three subgroups in Group $4(n=23)$ were forced to swim for $15 \mathrm{~min}$ and made to take a rest for $30 \mathrm{~min}$; then the maximum swimming time to fatigue was measured following the 
oral administration of RJ, 40-7d RJ, or the control solution at 10 min after the start of the rest period.

Muscle glycogen analysis. Immediately after the blood had been collected, the gastrocnemius muscles were removed, frozen in liquid nitrogen, and kept at $-80^{\circ} \mathrm{C}$ until analysis for glycogen concentration. The glycogen content was measured spectrophotometrically by the glucose oxidase method described elsewhere (29). Briefly, after hydrolysis of the muscle sample in $0.6 \mathrm{~N} \mathrm{HCl}$ at $100^{\circ} \mathrm{C}$ for $2 \mathrm{~h}$, the glucose residues were determined with a commercial kit (Glucose CII Test Wako, Wako Pure Chemical Industries, Osaka, Japan).

Analysis of serum L-lactic acid, glucose, and ammonia. Blood samples for lactate determination were immediately deproteinized in perchloric acids $(0.6 \mathrm{~N})$ and centrifuged, and the serum lactate concentration was determined with an L-lactic acid commercial kit (Boehringer Mannheim $\mathrm{GmbH}$, Mannheim, Germany). Serum ammonia was measured by using a commercial kit (Ammonia-Test Wako, Wako Pure Chemical Industries). Blood glucose concentration was measured with a Medisafe reader GR-101 (Terumo, Tokyo, Japan).

Quantitative analysis of several vitamins in RJ. The contents of vitamin $B_{1}$, vitamin $B_{2}$, vitamin $B_{6}$, folic acid, pantothenic acid, nicotinic acid, and biotin in RJ were quantitatively analyzed as described previously (10).

Determination of the concentrations of fatty acids in RJ. $\mathrm{RJ}(5 \mathrm{~g})$ was dissolved in $50 \mathrm{~mL}$ of $1 \mathrm{M} \mathrm{NaOH}$-ethanol solution. Thereafter, $150 \mathrm{~mL}$ of distilled water, $7 \mathrm{~mL}$ of $30 \%$ sulfuric acid, and $100 \mathrm{~mL}$ of diethylether were added in the suspension, and free fatty acids were extracted from RJ. Free fatty acids were transmethylated with boron trifluoride methanol at $100^{\circ} \mathrm{C}$ for $7 \mathrm{~min}$. The fatty acid methyl esters were separated and measured on a Shimadzu gas chromatograph (Shimadzu GC-17A, Shimadzu Seisakusho Ltd., Kyoto, Japan) equipped with flame ionization detector and DB-23 column $(0.25 \mathrm{~mm}$ i.d. $\times 30 \mathrm{~m})$. A temperature gradient program was used with an initial temperature of $170^{\circ} \mathrm{C}$, increasing at a rate of $10^{\circ} \mathrm{C} / \mathrm{min}$ to $250^{\circ} \mathrm{C}$. Identification of fatty acid methyl esters was made by comparison with the retention times of authentic standards. The content of 10-hydroxy-2-decenoic acid (10HDA) in RJ was determined by the method of Yamazaki et al. (30) with some modification.

Polyacrylamide gel electrophoresis (PAGE). NativePAGE was run with a 5-20\% gradient polyacrylamide gel by the method of Davis (31). SDS-PAGE was run with a $5-20 \%$ gradient polyacrylamide gel by the method of Laemmli (32).

Purification of 57-kDa protein. The purification of 57-kDa protein was conducted as described previously (10), with monitoring by the use of native PAGE. The purified $57-\mathrm{kDa}$ protein was dialyzed against distilled water and lyophilized.

Determination of the concentrations of proteins in RJ. For the quantification of protein constituents in RJ, the results of native PAGE of RJ proteins were analyzed by NIH image Ver. 1.62 (NIH, USA), using purified 57-kDa protein as a standard.

Materials. MiniPlate ${ }^{\mathrm{TM}} 100$ and MiniPlate ${ }^{\mathrm{TM}} 30$ were purchased from Millipore Co. (Bedford, USA). DEAE-Toyopearl 650M and TSK-gel G3000SW columns were purchased from Tosoh Co. (Tokyo, Japan). HiLoad $^{\mathrm{TM}}$ 16/10 Superdex 200 column and LMW electrophoresis calibration kit were purchased from Amersham Pharmacia Biotech (Uppsala, Sweden). Cosmosil $\mathrm{C}_{18}$ Econopak column was from Nacalai Tesque (Kyoto, Japan). L-column ODS was from the Chemical Evaluation Research Institute (Tokyo, Japan). DB-23 column was from J \& W Scientific Inc. (Folsom, CA). All other chemicals were of guaranteed reagent grade.

Statistics. Values are expressed as mean \pm SE. All statistical analysis was done by using one-way analysis of variance (ANOVA). Statistical data were calculated with the Stat View 5 software for the Macintosh (SAS Institute Inc., Cary, NC, USA). The level of $p<0.05$ was used as the criterion of statistical significance.

\section{RESULTS}

Effect of RJ on metabolic parameters after swimming once

The concentrations of serum lactate and muscle glycogen and serum glucose after 15 min of swimming, following administration of control solution, RJ, or 40$7 \mathrm{~d}$ RJ, are shown in Fig. 1. The concentrations of serum lactate, serum glucose, and muscle glycogen before swimming showed no significant differences among the three groups, suggesting that RJ administration did not affect the metabolic parameters related to carbohydrate metabolism during exercise. After $15 \mathrm{~min}$ of swimming, the serum lactate concentration in the RJ group was significantly lower than those in the other groups (relative to the control group, $p<0.01$; relative to the $40-7 \mathrm{~d}$ $\mathrm{RJ}$ group, $p<0.05)$. The amount of muscle glycogen remaining in the RJ group and the 40-7d RJ group tended to be higher than that in the control group. The serum glucose concentration after $15 \mathrm{~min}$ of swimming in the $\mathrm{RJ}$ group was significantly higher than that in the 40$7 \mathrm{~d}$ RJ group $(p<0.05)$, whereas no significant difference between the 40-7d RJ group and the control group was apparent.

It is common knowledge that blood ammonia accumulates during exercise (33-35). Since excess ammonia has a toxic effect on the central nervous system, exercise-induced ammonia accumulation may contribute to the induction of central fatigue (36). Therefore the serum ammonia concentration after swimming in groups given each sample was measured. The serum ammonia concentration in the RJ group was significantly lower than that in the control group $(p<0.01)$, whereas no significant difference between the 40-7d RJ group and the control group was apparent (Fig. 2). These results indicated that RJ administration before swimming could alleviate the fatigue of mice during exercise.

Effect of RJ on swimming endurance capacity

The mice were forced to swim for $15 \mathrm{~min}$ and made to take a rest for $30 \mathrm{~min}$. Thereafter they were subjected 
(A)

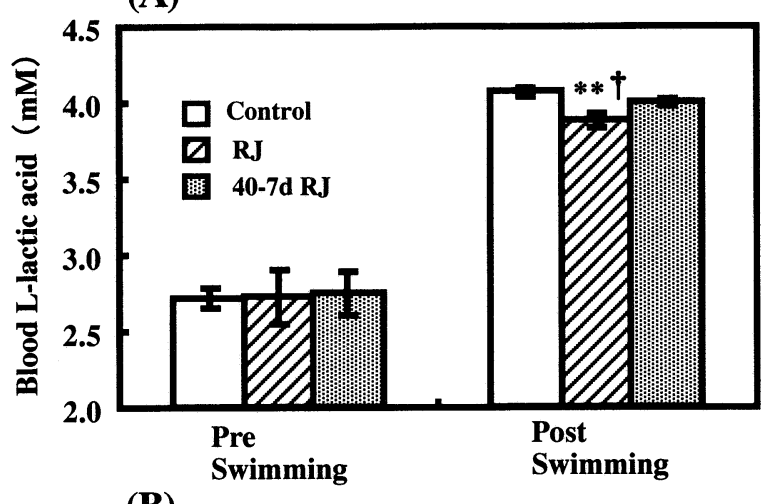

(B)

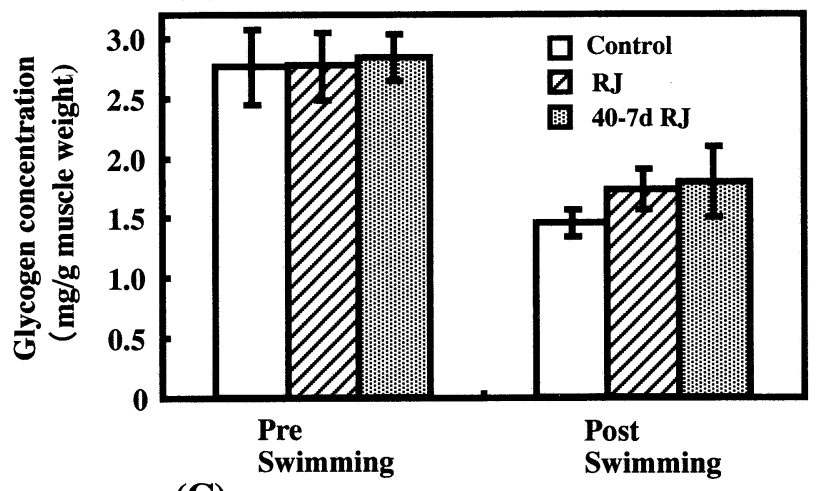

(C)

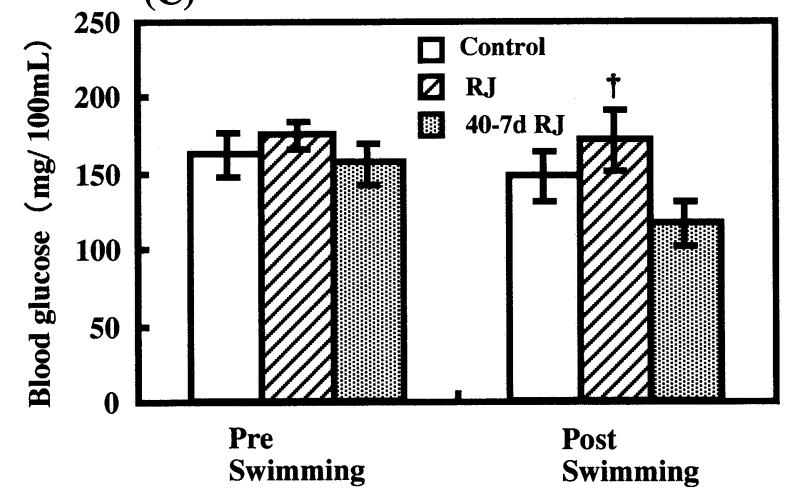

Fig. 1. Changes of blood lactate concentration, muscle glycogen concentration, and blood glucose concentration after swimming for $15 \mathrm{~min}$ once. Mice were administered RJ, 40-7d RJ, or the control solution at $48 \mathrm{~h}, 24 \mathrm{~h}$, and $0.5 \mathrm{~h}$ before swimming, then were subjected to forced swimming for $15 \mathrm{~min}$. Blood samples and gastrocnemius muscles were immediately collected before or after swimming for $15 \mathrm{~min}$. The concentrations of lactate and glucose in the blood were determined. The gastrocnemius muscles were also removed and stored at $-80^{\circ} \mathrm{C}$, and the glycogen concentration in muscle was measured. (A) blood L-lactic acid concentration, (B) muscle glycogen concentration, (C) blood glucose concentration. Each value represents the mean \pm SE for 4-7 mice, respectively. $40-7 \mathrm{~d}$ RJ, RJ stored at $40^{\circ} \mathrm{C}$ for $7 \mathrm{~d}$. Values significantly different from the control group are indicated by ${ }^{* *} p<0.01$. Values significantly different from the $40-7 \mathrm{~d}$ RJ group are indicated by ${ }^{\dagger} p<0.05$.

to forced swimming until fatigue, and the swimming capacity was measured. As shown in Fig. 3, the swimming capacities of the control group, the RJ group and

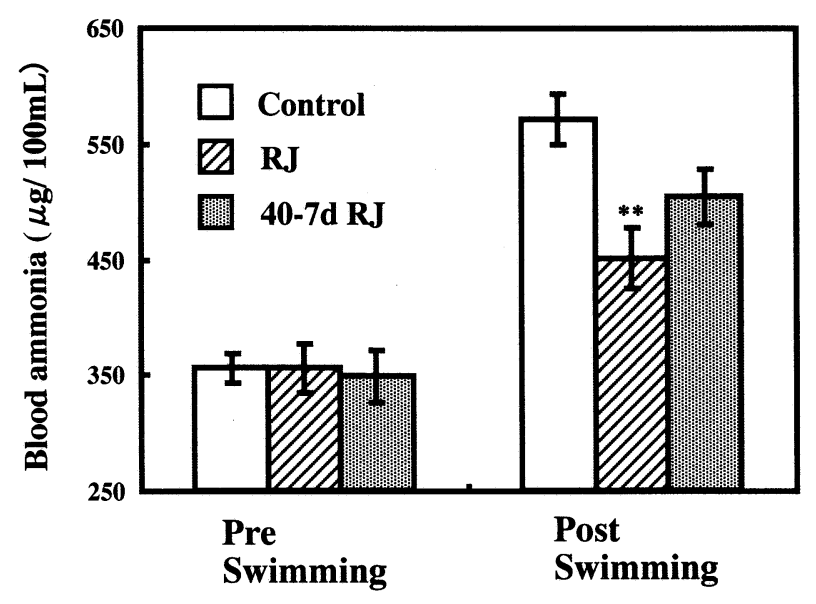

Fig. 2. Change of blood ammonia concentration after swimming for $15 \mathrm{~min}$ once. Mice were administered RJ, 40-7d RJ, or the control solution at $48 \mathrm{~h}, 24 \mathrm{~h}$, and $0.5 \mathrm{~h}$ before swimming, then were subjected to forced swimming for $15 \mathrm{~min}$. Blood samples were collected before or after swimming for $15 \mathrm{~min}$, and the concentration of ammonia in the blood was determined. Each value represents the mean \pm SE for 4-7 mice. 40-7d RJ, $\mathrm{RJ}$ stored at $40^{\circ} \mathrm{C}$ for $7 \mathrm{~d}$. Values significantly different from the control group are indicated by ${ }^{* *} p<0.01$.

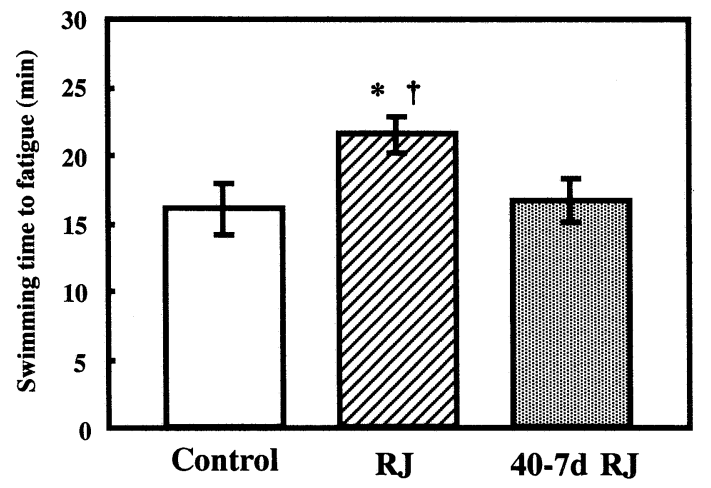

Fig. 3. Effect of RJ and RJ stored at $40^{\circ} \mathrm{C}$ for $7 \mathrm{~d}$ on the swimming capacity of mice. Mice were administered RJ, 40-7d RJ, or the control solution at $48 \mathrm{~h}, 24 \mathrm{~h}$, and $0.5 \mathrm{~h}$ before swimming. All mice were forced to swim for $15 \mathrm{~min}$ and made to take a rest for $30 \mathrm{~min}$. The maximum swimming time to fatigue was then measured. Each value represents the mean \pm SE for $7-8$ mice. $40-7 \mathrm{~d}$ RJ, RJ stored at $40^{\circ} \mathrm{C}$ for $7 \mathrm{~d}$. Values significantly different from the control group are indicated by $* p<0.05$. Values significantly different from the 40 $7 \mathrm{~d}$ RJ group are indicated by ${ }^{\dagger} p<0.05$.

the $40-7 \mathrm{~d}$ RJ group were $16.1 \pm 1.8 \mathrm{~min}, 21.6 \pm 1.3$ $\mathrm{min}$, and $16.7 \pm 1.6 \mathrm{~min}$, respectively. The swimming time until fatigue of the RJ group was significantly longer than those of the other groups (relative to the control group, $p<0.05$; relative to the $40-7 \mathrm{~d}$ RJ group, $p<0.05)$.

Effect of RJ on metabolic parameters during another swimming period

Mice were forced to swim again for $15 \mathrm{~min}$ after swimming once, followed by a rest period, and metabolic parameters after swimming again were measured. 
(A)

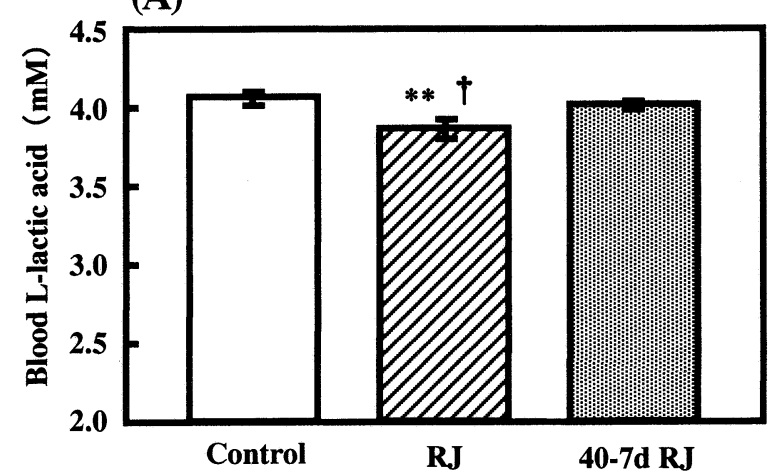

(B)

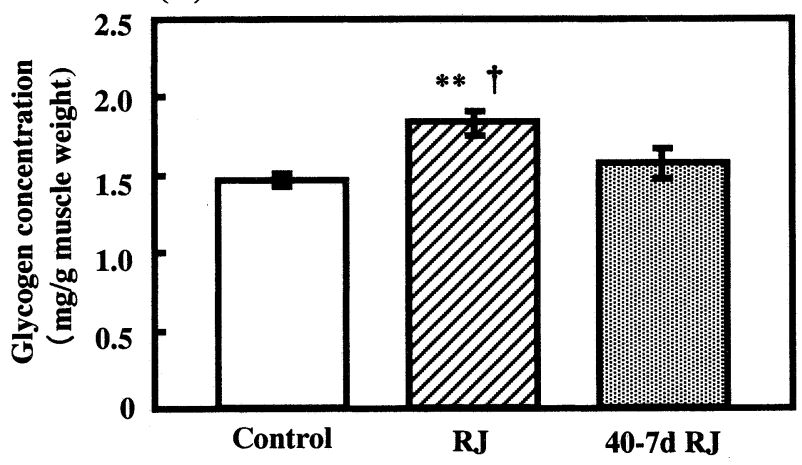

(C)

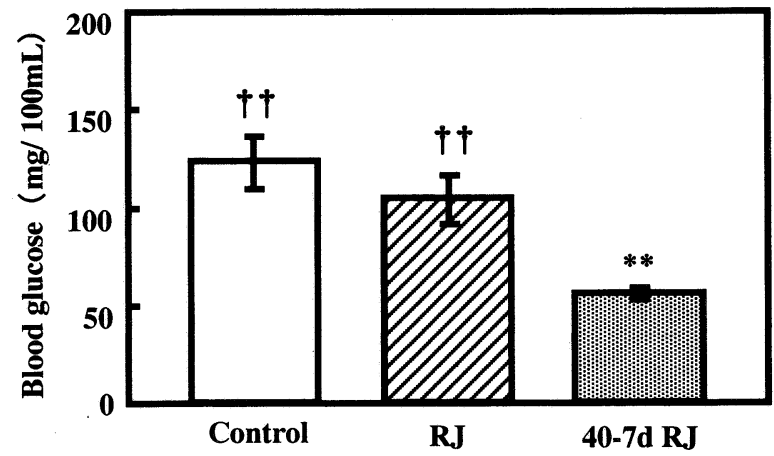

Fig. 4. Changes of blood lactate concentration, muscle glycogen concentration, and blood glucose concentration after a 15-min swim following a first swimming session, followed by a rest period. The mice were administered RJ, $40-7 \mathrm{~d}$ RJ, or the control solution at $48 \mathrm{~h}, 24 \mathrm{~h}$, and $0.5 \mathrm{~h}$ before swimming. All mice were forced to swim for $15 \mathrm{~min}$ and made to take a rest for $30 \mathrm{~min}$. They were again subjected to forced swimming for $15 \mathrm{~min}$. The details of the methods for the measurement of metabolic parameters are given in Materials and Methods. (A) blood L-lactic acid concentration, (B) muscle glycogen concentration, (C) blood glucose concentration. Each value represents the mean \pm SE for 8 mice. $40-7 \mathrm{~d}$ RJ, RJ stored at $40^{\circ} \mathrm{C}$ for $7 \mathrm{~d}$. Values significantly different from the control group are indicated by ${ }^{* *} p<0.01$. Values significantly different from the $40-7 \mathrm{~d}$ RJ group are indicated by ${ }^{\dagger} p<0.05$ and ${ }^{\dagger \dagger} p<0.01$.

As shown in Fig. 4, the serum lactate concentration in the RJ group was significantly lower than those in the other groups (relative to the control group, $p<0.01$; relative to the $40-7 \mathrm{~d}$ RJ group, $p<0.05$ ). The concentration of muscle glycogen remaining in the RJ group was

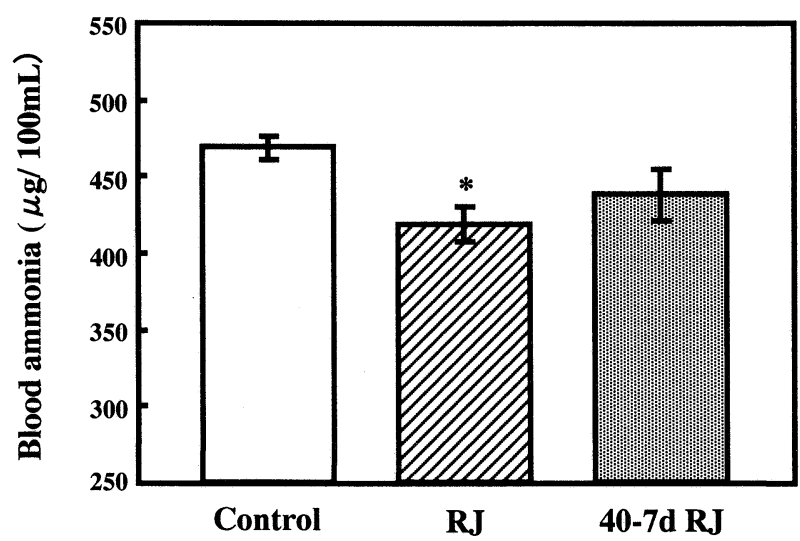

Fig. 5. Change of blood ammonia concentration after a 15-min swim following a first swimming session, followed by a rest period. The mice were administered RJ, $40-7 \mathrm{~d}$ RJ, or the control solution at $48 \mathrm{~h}, 24 \mathrm{~h}$, and $0.5 \mathrm{~h}$ before swimming. All mice were forced to swim for $15 \mathrm{~min}$ and made to take a rest for $30 \mathrm{~min}$. Mice were again subjected to forced swimming for $15 \mathrm{~min}$, blood samples were immediately collected, and the concentration of blood ammonia was determined. Each value represents the mean \pm SE for 8 mice. $40-7 \mathrm{~d}$ RJ, RJ stored at $40^{\circ} \mathrm{C}$ for $7 \mathrm{~d}$. Values significantly different from the control group are indicated by ${ }^{*} p<0.05$.

also significantly higher than those in the other groups (relative to the control group, $p<0.01$; relative to the $40-7 \mathrm{~d}$ RJ group, $p<0.05$ ). The serum glucose concentration after swimming again following the rest in the 40-7d RJ group was significantly lower than those in the other groups (relative to the control group, $p<0.01$; relative to the RJ group, $p<0.01$ ), whereas no significant difference between the RJ group and the control group was observed in the serum glucose concentration. The serum ammonia concentration after $15 \mathrm{~min}$ of a second swimming following the rest in the RJ group was significantly lower than that in the control group $(p<0.05)$, whereas no significant difference between the 40-7d RJ group and the control group was apparent (Fig. 5). These results and the result of experiment 2 suggest that RJ improved the physical fatigue induced by further exercise after the mice had been exhausted by an initial exercise, followed by a rest.

Comparison of the contents of various fatty acids in $R J$ stored at $-20^{\circ} \mathrm{C}$ and in $\mathrm{RJ}$ stored at $40^{\circ} \mathrm{C}$ for $7 \mathrm{~d}$

We previously reported that the contents of various vitamins such as vitamin $B_{1}$, vitamin $B_{2}$, vitamin $B_{6}$, folic acid, pantothenic acid, nicotinic acid, and biotin in RJ did not change during storage at $40^{\circ} \mathrm{C}$ for $7 \mathrm{~d}(10)$. The same results were observed in RJ samples used in this study (data not shown). Furthermore, the contents of fatty acids in RJ stored at $-20^{\circ} \mathrm{C}$ and $40^{\circ} \mathrm{C}$ for $7 \mathrm{~d}$ were measured. $\mathrm{RJ}$ stored at $-20^{\circ} \mathrm{C}$ contained caprylic acid $(7.0 \mathrm{mg} / 100 \mathrm{~g} \mathrm{RJ}), 10-\mathrm{HDA}(1.67 \mathrm{~g} / 100 \mathrm{~g} \mathrm{RJ})$, palmitic acid $(10.0 \mathrm{mg} / 100 \mathrm{~g} \mathrm{RJ})$, oleic acid $(13.0 \mathrm{mg} /$ $100 \mathrm{~g} \mathrm{RJ})$, and linolenic acid $(21.0 \mathrm{mg} / 100 \mathrm{~g} \mathrm{RJ})$, whereas RJ stored at $40^{\circ} \mathrm{C}$ for $7 \mathrm{~d}$ contained caprylic acid $(7.0 \mathrm{mg} / 100 \mathrm{~g} \mathrm{RJ}), 10-\mathrm{HDA}(1.70 \mathrm{~g} / 100 \mathrm{~g} \mathrm{RJ})$, palmitic acid $(11.0 \mathrm{mg} / 100 \mathrm{~g} \mathrm{RJ})$, oleic acid $(14.0 \mathrm{mg} /$ 
$100 \mathrm{~g} \mathrm{RJ})$, and linolenic acid (20.0 mg/100 g RJ). No significant differences between the two RJ samples were observed in the contents of these fatty acids in RJ samples.

Analysis of protein in $\mathrm{RJ}$ stored at $-20^{\circ} \mathrm{C}$ and in $\mathrm{RJ}$ stored at $40^{\circ} \mathrm{C}$ for $7 \mathrm{~d}$

To investigate whether compositional changes of proteins in RJ occurred during storage, proteins in RJ stored at $-20^{\circ} \mathrm{C}$ and at $40^{\circ} \mathrm{C}$ for $7 \mathrm{~d}$ were analyzed by SDS-PAGE and native PAGE. The electrophoretic profile of RJ proteins stored at $-20^{\circ} \mathrm{C}$ for $7 \mathrm{~d}$ was almost identical to that of RJ proteins stored at $40^{\circ} \mathrm{C}$ for $7 \mathrm{~d}$ on SDSPAGE, and the results of native PAGE showed that 57$\mathrm{kDa}$ protein, which we previously identified as a possible freshness marker of RJ (10), and royal jelly protein-2 (RJP-2) were specifically degraded when RJ samples were stored at $40^{\circ} \mathrm{C}$ (data not shown). The concentrations of 57-kDa protein and RJP-2 in the two RJ samples were calculated by the use of the purified $57-\mathrm{kDa}$ protein as a standard, from the results of native PAGE of RJ proteins. $57-\mathrm{kDa}$ protein concentration accounted for $1.6 \%$ of the weight of RJ stored at $-20^{\circ} \mathrm{C}$, whereas the RJP-2 content was $0.1 \%$ by weight. The amount of 57 $\mathrm{kDa}$ protein in fresh RJ was about 16-fold higher than that of RJP-2. The $57-\mathrm{kDa}$ protein was degraded to $9.4 \%$ of the initial content during storage at $40^{\circ} \mathrm{C}$ for 7 d. However, the residual amount of RJP-2 was $40 \%$ of the initial content under the same storage conditions.

\section{DISCUSSION}

In this study, the antifatigue effect of fresh RJ on mice was evaluated by the use of an adjustable-current swimming pool, which is a new forced swimming apparatus for measuring the maximum swimming time (21). This apparatus has many advantages for evaluating the endurance capacity of mice, including higher reproducibility than treadmill running or forced swimming with a weight attached to the tail (21). We found that RJ administration before swimming enhanced the swimming endurance of mice in repeated swimming, and the blood lactate accumulation and the consumption of muscle glycogen in the RJ group were significantly lower than those in the other groups. Little difference was found between the concentrations of lactate in blood and muscle glycogen remaining after the first swim and those after the second swim. Therefore it was considered that RJ administered before swimming made mice resistant to the physical fatigue after the first swim, and the antifatigue effect was maintained in the second forced swim. Mice in the RJ group showed a lower depletion of muscle glycogen and blood glucose and a reduced formation of blood lactate after swimming, which implies that the RJ administration reduced the ratio of carbohydrate utilization during exercise, delaying the onset of fatigue. These findings suggest that the oxidative systems producing energy for exercise, such as the tricarboxylic acid cycle (TCA cycle) and mitochondrial oxidation, were promoted in the RJ group without dependency on glycolysis as a fuel source during exercise. Consequently, mice given RJ have a pro- longed swimming endurance capacity. However, mice given RJ stored at $40^{\circ} \mathrm{C}$ for $7 \mathrm{~d}$, in which a deterioration of physical properties and an increase of viscosity were observed, did not show increased swimming endurance capacity, and their accumulation of serum lactate after swimming and consumption of muscle glycogen were similar to those of the control group. These results suggest that the active component in RJ is degraded during the storage of RJ at a high temperature for a long period.

Physical exercise or movement accelerates the production of ammonia in the muscle purine-nucleotide cycle (37), increasing the ammonia concentration in blood (33-35). The predominant source of ammonia production during exercise seems to be due to the deamination of AMP in muscle by adenylate deaminase (37-39). Although glutamine dehydrogenase is mainly responsible for the liberation of ammonia from amino acids, the activity of this enzyme is reported to be absent in skeletal muscle (37). Heald demonstrated that ammonia may interfere directly with the mechanical and electrophysiological responses of skeletal muscle (40). It has also been suggested that the ammonia released from muscle during exercise may have direct access to brain tissue, via the circulation, and it could cause toxic effects in the central nervous system (41). Interestingly, we found that the administration of RJ significantly suppressed the increase of serum ammonia concentration after swimming in comparison with the control group, while RJ stored at $40^{\circ} \mathrm{C}$ for $7 \mathrm{~d}$ was ineffective. Therefore, these results suggested that fresh $\mathrm{RJ}$ stored at $-20^{\circ} \mathrm{C}$ immediately after collection might alleviate central fatigue after physical exercise. Wilkerson et al. (42) found a significant correlation between the concentration of peripheral venous ammonia and the concomitant concentrations of venous lactic acid both during and after treadmill exercise in humans. Similarly, a significant correlation between blood ammonia and blood lactate levels was found in mice after swimming in the present study $(r=0.651, p<0.001)$ (data not shown). Ammonium ions increase glycolysis by directly increasing the activity of phosphofructokinase, one of the ratelimiting enzymes of glycolysis (37). Furthermore, pyruvate carboxylation (43), which is the first reaction of glyconeogenesis, and isocitrate dehydrogenase and pyruvate dehydrogenase $(44,45)$, which are enzymes of the TCA cycle, are also inhibited in the presence of ammonia. These changes in glycolytic and TCA cycle metabolism that result from increased ammonia concentrations may lead to lactate accumulation (46). Ammonia production during exercise seems to be closely associated with the accumulation of lactate during exercise.

We next analyzed the constituents in RJ stored at $-20^{\circ} \mathrm{C}$ and $40^{\circ} \mathrm{C}$ for $7 \mathrm{~d}$ to elucidate why RJ stored at $-20^{\circ} \mathrm{C}$ exhibited the antifatigue effect, while RJ stored at $40^{\circ} \mathrm{C}$ for $7 \mathrm{~d}$ did not. Takenaka et al. (9) have previously examined the influence of storage conditions on the composition of RJ and reported that the concentrations of amino acids and sugars in RJ did not change 
during storage at room temperature for 2 mo. The contents of 10-HDA (10:1), which shows antitumor activity (15-17) and antibacterial activity (6), and other fatty acids in RJ also underwent no change during the storage of RJ at $40^{\circ} \mathrm{C}$ for $7 \mathrm{~d}$. Vitamin $\mathrm{B}_{1}$, pantothenic acid, and nicotinic acid are known to influence fatigue after exercise (47-49). However, no significant differences between the two RJ samples were observed in the contents of various vitamins. In our previous study, we reported that $57-\mathrm{kDa}$ protein in $\mathrm{RJ}$ was specifically degraded in proportion to both storage temperature and storage period (10). In the present study, the $57-\mathrm{kDa}$ protein accounted for approximately $1.6 \%$ of RJ and declined to $9.4 \%$ of the initial concentration during storage at $40^{\circ} \mathrm{C}$ for $7 \mathrm{~d}$. When mice were fed commercial diets containing diverse types of RJ, in which the 57$\mathrm{kDa}$ protein concentrations were different, and were subjected to forced swimming with an adjustable-current water pool, the increase of swimming endurance capacities in several RJ-fed groups at $2 \mathrm{wk}$ after pretraining was proportional to the $57-\mathrm{kDa}$ protein concentration in the RJ given to these mice (data not shown). These results suggest a close relationship between the freshness of RJ and the antifatigue effect of RJ.

We previously found that $57-\mathrm{kDa}$ protein stimulates hepatocyte DNA synthesis and prolongs the proliferation of primary cultured rat hepatocytes through antiapoptotic action, as well as increasing albumin production (50). The 57-kDa protein seems to be a mitogen, such as epidermal growth factor (EGF) and hepatocyte growth factor (HGF). Lactate produced in the muscle during exercise is transferred to the liver for conversion into glucose by gluconeogenesis through the Cori cycle (51). EGF has been shown to stimulate gluconeogenesis from lactate in rat liver by decreasing the activity of pyruvate kinase $(52,53)$, and to stimulate the TCA cycle by activation of the metabolic flux through the mitochondrial 2-oxoglutarate dehydrogenase reaction (54). Therefore, $57-\mathrm{kDa}$ protein may act to stimulate gluconeogenesis and the TCA cycle in liver, like EGF, thereby suppressing lactate accumulation and glycogen depletion during swimming. However, further study is needed to elucidate the mechanism of the effect of RJ on fatigue.

In conclusion, we found that fresh, but not improperly stored, RJ increased the swimming endurance capacity of mice and decreased the accumulation of blood lactate and blood ammonia and the depletion of muscle glycogen after exercise. A quantitative analysis of the constituents of fresh and stored RJ suggested that the antifatigue effect of RJ may be closely related with the freshness of RJ.

\section{Acknowledgments}

We thank Dr. T. Fushiki, Professor, Graduate School of Agriculture, Kyoto University, for his helpful advice.

\section{REFERENCES}

1) Haydak MH. 1970. Honey bee nutrition. Ann Rev
Entomol 15: 143-156.

2) Patel NG, Haydak MH, Gochnauer TA. 1960. Electrophoretic components of the proteins in honeybee larval food. Nature 186: 633-634.

3) Takenaka T. 1982. Chemical composition of royal jelly. Honeybee Sci 3: 69-74.

4) Echigo T, Takenaka T, Yatsunami K. 1986. Comparative studies on chemical composition of honey, royal jelly and pollen loads. Bull Fac Agric Tamagawa Univ 26: 1-12.

5) Howe SR, Dimick PS, Benton AW. 1985. Composition of freshly harvested and commercial royal jelly. J Apic Res 24: 52-61.

6) Blum MS, Novak AF, Taber S. 1959. 10-Hydroxy- $\Delta^{2}$-decenoic acid, an antibiotic found in royal jelly. Science 130: $452-453$.

7) Fujiwara S, Imai J, Fujiwara M, Yaeshima T, Kawashima T, Kobayashi K. 1990. A potent antibacterial protein in royal jelly. J Biol Chem 265: 11333-11337.

8) Kato A, Onodera M, Ishijima Y. 1988. Effect of royal jelly on development of genital organs in male mice. $J$ Tokyo Vet Anim Sci 35: 1-4.

9) Takenaka T, Yatsunami K, Echigo T. 1986. Changes in quality of royal jelly during storage. Nippon Shokuhin Kogyo Gakkaishi 33: 1-7 (in Japanese).

10) Kamakura M, Fukuda T, Fukushima M, Yonekura M. 2001. Storage-dependent degradation of 57-kDa protein in royal jelly: a possible marker for freshness. Biosci Biotechnol Biochem 65: 277-284.

11) Shinoda M, Nakajin S, Oikawa T, Sato K, Kamogawa A, Akiyama Y. 1978. Biochemical studies on vasodilative factor in royal jelly. Yakugaku Zasshi 98: 139-145 (in Japanese).

12) Kawamura J. 1961. Influence of gelee royale on embryos. J Showa Med Assoc 20: 1465-1471 (in Japanese).

13) Yatsunami K, Echigo T. 1985. Antibacterial action of royal jelly. Bull Fac Agric Tamagawa Univ 25: 13-22.

14) Tamura T, Fujii A, Kuboyama N. 1987. Antitumor effect of royal jelly. Folia Pharmacol Japon 89: 73-80 (in Japanese).

15) Townsend GF, Morgan JF, Hazlett B. 1959. Activity of 10-hydroxydecenoic acid from royal jelly against experimental leukemia and ascitic tumors. Nature 183: 1270-1271.

16) Townsend GF, Morgan JF, Tolnai S, Hazlett B, Morton HJ, Shuel RW. 1960. Studies on the in vitro antitumor activity of fatty acid I. 10-Hydroxy-2-decenoic acid from royal jelly. Cancer Res 20: 503-510.

17) Townsend GF, Brown WH, Felauer EE, Hazlett B. 1961. Studies on the in vitro antitumor activity of fatty acid IV. The esters of acids closely related to 10-hydroxy-2decenoic acid from royal jelly against transplantable mouse leukemia. Can J Biochem Physiol 39: 17651770.

18) Nakajin S, Okiyama K, Yamashita S, Akiyama Y, Shinoda M. 1982. Effect of royal jelly on experimental hypercholesterolemia in rabbits. Yakugaku Zasshi 36: 65-69 (in Japanese).

19) Fujii A, Kobayashi S, Kuboyama N, Furukawa Y, Kaneko Y, Ishihama S, Yamamoto H, Tamura T. 1990. Augmentation of wound healing by royal jelly (RJ) in streptozotocin-diabetic rats. Jpn J Pharmacol 53: 331337.

20) Morris DH, Stare FJ. 1993. Unproven diet therapies in 
the treatment of the chronic fatigue syndrome. Arch Fam Med 2: 181-186.

21) Matsumoto K, Ishihara K, Tanaka K, Inoue K, Fushiki T. 1996. An adjustable-current swimming pool for the evaluation of endurance capacity of mice. J Appl Physiol 81: 1843-1849.

22) Hatta H. 1994. Treadmill running in rats and mice. Jpn J Biochem Exerc 7: 15-19.

23) Hatta H, Soma R, Atomi Y. 1994. Effect of endurance training on oxidation of lactate in mice after supramaximal exercise. Comp Biochem Physiol A Comp Physiol 107A: 27-30.

24) Danadai BS. 1994. Effect of caffeine on the metabolism of rats exercising by swimming. Braz J Med Bio Res 27: 2481-2485.

25) Montoye HJ, Nelson R, Johnson P, MacNab R. 1960. Effects of exercise on swimming endurance and organ weight in mature rats. Res $Q$ 31: 474-484.

26) Pierce GN, Kutryk MJB, Dhalla KS, Beamish RE, Dhalla NS. 1984. Biochemical alterations in heart after exhaustive swimming in rats. J Appl Physiol 57: 326331.

27) Wilber CG. 1959. Some factors which are correlated with swimming capacity in guinea pigs. J Appl Physiol 14: 199-203.

28) Kim KM, Kawada T, Ishihara K, Inoue K, Fushiki T. 1997. Increase in swimming endurance capacity of mice by capsaicin-induced adrenal catecholamine secretion. Biosci Biotechnol Biochem 61: 1718-1723.

29) Fushiki T, Matsumoto K, Inoue K, Kawada T, Sugimoto E. 1995. Swimming endurance capacity of mice is increased by chronic consumption of medium-chain triglycerides. J Nutr 125: 531-539.

30) Yamazaki K, Hashimoto A, Kokusenya Y, Miyamoto T, Nakai H, Sato T. 1995. Assay method of constituents of crude drugs in drinkable preparations by high performance liquid chromatography: study of each assay method of main constituents of crude drugs. Yakugaku Zasshi 115: 62-71 (in Japanese).

31) Davis BJ. 1964. Electrophoresis of proteins. Ann NY Acad Sci 121: 404-427.

32) Laemmli UK. 1970. Cleavage of structural proteins during the assembly of the head bacteriophage T4. Nature 227: 680-685.

33) Eriksson LS, Broberg S, Bjorkman O, Wahren J. 1985. Ammonia metabolism during exercise in man. Clin Physiol 5: 325-336.

34) Banister EW, Allen ME, Mekjavic IB, Singh AK, Legge B, Mutch BJC. 1983. The time course of ammonia and lactate accumulation in blood during bicycle exercise. Eur J Appl Physiol 51: 195-202.

35) Buono MJ, Clancy TR, Cook JR. 1984. Blood lactate ammonia ion accumulation during graded exercise in human. J Appl Physiol 57: 135-139.

36) Schenker S, McCandless DW, Brophy E, Lewis MS. 1967. Studies on the intercerebral toxicity of ammonia. J Clin Invest 46: 838-848.

37) Lowenstein JM. 1972. Ammonia production in muscle and other tissue: the purine nucleotide cycle. Physiol Rev 52: 382-414.
38) Goodman MN, Lowenstein JM. 1977. The purine nucleotide cycle; studies of ammonia production by skeletal muscle in situ and in perfused preparations. $J$ Biol Chem 252: 5054-5060.

39) Lowenstein JM, Tornheim K. 1971. Ammonia production in muscle; the purine nucleotide cycle. Science 171: $387-400$.

40) Heald DE. 1975. Influence of ammonium ions on mechanical and electrophysiological responses of skeletal muscle. Am J Physiol 229: 1174-1179.

41) Barnes RH, Labadan BA, Siyamoglu B, Bradfield RB. 1964. Effects of exercise and administration of aspartic acid on blood ammonia in the rat. Am J Physiol 207: 1242-1246.

42) Wilkerson JE, Batterton DL, Horvath SM. 1977. Exercise induced changes in blood ammonia levels in humans. Eur J Appl Physiol 37: 255-263.

43) Bryla J, Niedzwiecka A. 1979. Relationship between pyruvate carboxylation and citrulline synthesis in rat liver mitochondria: the effect of ammonia and energy. Int J Biochem 10: 235-239.

44) Katanuma N, Okada M, Nishii Y. 1966. Regulation of the urea cycle and TCA cycle by ammonia In: Advance in Enzyme Regulation (Wever G, ed.), Vol. 4, p 317-335. Pergamon Press, New York.

45) Worcel A, Erecinska M. 1962. Mechanism of inhibitory action of ammonia on the respiration of rat-liver mitochondria. Biochem Biophys Acta 65: 27-33.

46) Koyuncuoclu H, Keyer M, Simsek S, Sagduyu H. 1978. Ammonia intoxication: changes of brain levels of putative neurotransmitter and related compounds and its relevance to hepatic coma. Pharmacol Res Commun 10: 787-807.

47) Suzuki M, Itokawa Y. 1996. Effects of thiamine supplementation on exercise-induced fatigue. Metab Brain Dis 11: 95-106.

48) Shibata K, Matsumoto K, Fushiki T, Sugimoto E. 1994. Effect of exercise on the metabolism of NAD. Jpn J Biochem Exercise 6: 75-81.

49) Saito H, Bao T. 1984. Effects of red ginseng, vitamins and their preparations (I): effect on forced exercise in mice. Yakuri to Chiryo 12: 1453-1459 (in Japanese).

50) Kamakura M, Suenobu N, Fukushima M. 2001. 57$\mathrm{kDa}$ protein in royal jelly enhances proliferation of primary cultured rat hepatocytes and increases albumin production in the absence of serum. Biochem Biophys Res Commun 282: 865-874.

51) Cori CF. 1981. The glucose-lactic acid cycle and gluconeogenesis. Curr Top Cell Regul 18: 377-387.

52) Moule SK, McGivan JF. 1988. Epidermal-growth-factor stimulation of gluconeogenesis in isolated rat hepatocytes involves the inactivation of pyruvate kinase. Biochem J 255: 361-364.

53) Moule SK, McGivan JD. 1991. Epidermal-growth-factor stimulates the phosphorylation of pyruvate kinase in freshly isolated rat hepatocytes. FEBS Lett 280: 37-40.

54) Rashed SM, Patel TB. 1991. Regulation of hepatic energy metabolism by epidermal growth factor. Eur J Biochem 197: 805-813. 